\title{
Climate Variation and Hydropower Generation in Samanalawewa Hydropower Scheme, Sri Lanka
}

\author{
Geeshani Dabare, Miyuru B. Gunathilake, Nandika Miguntanna, \\ Kamal Laksiri and Upaka Rathnayake
}

\begin{abstract}
Climate variation is a challenging scenario on water resources. Therefore, runoffbased hydropower development stations are at an alarming situation across the world and the hydropower industry has significantly been affected. Therefore, it would be interesting to understand the impact of climate change on hydropower development in a country, where a significant energy contribution takes place by the renewable hydropower. However, such studies in Sri Lanka are limited mainly due to data scarcity. Nevertheless, this study was carried out to understand the relationships between the rainfall and the hydropower development in one of the major hydropower developments in Sri Lanka, Samanalawewa hydropower station. Non-parametric statistical trend analyses were carried out to the monthly rainfall over 26 years for the catchment rainfall. As the initial step, the link between rainfall and hydropower development was tested using the Pearson's correlation coefficient. Interestingly, results revealed positive rainfall trends over the catchment. The correlation coefficient suggests that there is an acceptable correlation between the rainfall and the hydropower development. However, non-linear analysis is proposed to achieve more sound conclusions. Initial results revealed that there is no adverse impact to the inflow of the reservoir due to the on-going climate change.
\end{abstract}

Keywords: Climate variability, Correlation coefficient, Rainfall, Samanalawewa hydropower plant, Trend analysis

\section{Introduction}

Energy supply according to the demand is one of the key components in human life. Not only human life but also animal life (at least up to some extent) cannot be sustained without energy in the modern day. But, on the other hand, energy supply has well been identified as one of the major causes for climatic change through greenhouse gas emissions [1]. Therefore, the green energy supply is a demanding topic in many of the discussion tables.

Climate is inherently a variable. It varies both spatially and temporally. The world, as a single unit, experiences the impacts of climate change. Many researchers believe that the anthropogenic activities have increased the impact of climate change [2], [3]. Climate change today is one among the largest concerns for today's world and most of the impacts of climate change are irreversible. The impacts are not only directed to environmental sustainability but also to social and economic sustainability.

Sea level rise, melting of glaziers and temperature increases are several visible impacts of the climate change. However, there are number of invisible impacts from the climate change [4], [5]. Reduction of hydropower generation from existing hydropower plants is one such example for unattended impacts. The major renewable source for electricity generation worldwide, supplying $71 \%$ of all sustainable electricity at the end of 2015, is hydropower [6]. The main component of hydropower generation is surface overflow, which depends entirely on rainfall. Therefore, climate change has a direct impact on the hydropower generation. Drought climates can decrease the generation, while stormy conditions can lead to the maximum possible generation. The latter would not be of much interest to the communities, unless there is a threat of flooding.

Miss. Geeshani Dabare, Civil Engineering Bachelor's student, Sri Lanka Technological Campus, Padukka.

Email:geeshani94@gmail.com

Eng. Miyuru B. Gunathilake, AMIE(SL) B.Sc. Eng. (Hons) (AIT), M. Eng. (AIT), Civil Engineer, Central Engineering Services (Pvt) Limited, Colombo.

Email:miyurubandaragunathilake@gmail.com (iD) https://orcid.org/0000-0001-7052-1942

Eng. (Dr.) Nandika Miguntanna, B.Sc. Eng. (Hons) (Peradeniya), PhD (QUT), Senior Lecturer, Sri Lanka Technological Campus, Padukka.

Eng. (Dr.) Kamal Laksiri, FIE(SL), BSc. Eng. (Hons) (Moratuwa). M.Sc. (NTNU), PhD (Saga). Project Director, Broadlands Hydropower Project, Ceylon Electricity Board.

Email:kamallaksiri@hotmail.com

Eng. (Dr.) Upaka Rathnayake, BSc. Eng. (Hons) (Peradeniya). M. Eng. (Hokkaido), PhD (Strathclyde, Scotland). Senior Lecturer, Sri Lanka Institute of Information Technology, Malabe.

Email:upakasanjeewa@gmail.com

(iD https://orcid.org/0000-0001-7052-1942 
Usually hydropower is a less expensive energy source [7]. Therefore, not so many people would like to see the reduction of hydropower generation due to the climate change. Nevertheless, it is the reality.

When it comes to the Sri Lankan context, $46 \%$ of the total electricity generated in the year 2015 was by hydropower plants $(38 \%)$ and mini hydro power plants (8\%) [8]. Sri Lanka being a tropical country is particularly at risk of effects of climate change and variability because of global warming and anthropogenic activities. Most of the hydropower plants are located around a region of reservoirs. Therefore, decreasing and increasing of water levels in these water bodies due to seasonal droughts, monsoon rains etc., is affecting the production capacity of the power plants. Due to drought condition during the year 2016, the hydropower plants including mini hydro plants could contribute only $29.7 \%$ to the total power generation in the year as against $46 \%$ in the previous year. This was a decrease of $29 \%$ from what they contributed in the year 2015 [8].

Therefore, this study presents initial analysis of the impacts of climate change in hydroelectric power generation in Sri Lanka. As an application of the research work carried out here, Samanalawewa hydropower plant was selected to be the case study. The Samanalawewa reservoir is one among the largest and important reservoirs in the country and it is in the Sabaragamuwa province. The reservoir is an important reservoir due to its seepage leak [9]. There were many researches on this seepage leak and it is believed to be happening from the bed of the reservoir [10]. Trend analyses for monthly rainfall are presented for the catchment and then the rainfalls are analysed for their correlation to the monthly electricity generation for 26 years. Therefore, the authors believe that this is an initial study of identifying the relationships among the rainfall and electricity power generation and the potential impacts of the climate change to the hydropower generation. However, linear analysis is considered in this analysis.

\section{Statistical Approach of the Climatic Data}

\subsection{Homogeneity of Rainfall}

Climate data over a long period to a particular location can be inhomogeneous due to many reasons [11]. This could be due to location difference of the rain gauge, differences in the height of the measurements, instrument changes over time, recoding differences etc. Therefore, the data can be inhomogeneous. There are several ways of checking the homogeneity of the rainfall records in the literature like graphical methods; however, statistical methods have taken much attention from the research communities [12].

The quality of a climatic trend analysis is totally dependent on the quality of the climatic data used. Therefore, it is important to check the homogeneity of the climatic data prior to trend analysis. Various statistical tests are carried out to check the homogeneity of the climatic data. Pettit's test [13], Buishand's test [11], [14], Standard Normal Homogeneity Test (SNHT) [15] and von Neumann's test [13], [16] are widely used tests to check homogeneity. More details on these tests can be found in references [17] and [18].

\subsection{Mann-Kendall Test}

Among other non-parametric tests, MannKendall test is widely used by many researchers [19], [20], [21] in searching climatic trends. It is used to identify the increasing or decreasing trends in a continuous climatic data set. The Mann-Kendall statistics $S$ is calculated using the following equations (1) and (2).

$$
\begin{gathered}
S=\sum_{i=1}^{n-1} \sum_{j=i+1}^{n} \operatorname{sgn}\left(x_{i}-x_{j}\right) \\
\operatorname{sgn}\left(x_{i}-x_{j}\right)=\left\{\begin{array}{ccc}
1, & x_{i}-x_{j} & >0 \\
0, & x_{i}-x_{j} & =0 \\
-1, & x_{i}-x_{j} & <0
\end{array}\right\}
\end{gathered}
$$

where $x_{i}$ and $x_{j}$ are the climate data values in months/seasons/years $i$ and $j, j>i$, respectively. Mann-Kendall test only provides a qualitative analysis of the trend, which is significantly increasing or decreasing. Therefore, Sen's slope estimator is usually coupled with Mann-Kendall test to find the quantitative analysis of the trend, if any. More details about the Mann-Kendall test can be found in Khaniya et al. [22].

\subsection{Sen's Slope Estimator Test}

Sen's slope test estimates the numerical value of the identified trend. This is the slope of the data series against time [23], [24], [25], [26]. Sen's slope is mathematically presented in the following equations (3) and (4).

$$
d_{k}=\frac{x_{j}-x_{i}}{j-i} ; \text { for } 1 \leq i \leq j \leq n
$$


where $d_{k}, x_{i}, x_{j}$ and $n$ are slope, data values at time $i$, data values at time $j$ and number of data, respectively. The Sen's slope estimator, $Q_{i}$, is calculated using the equation (4) and it is the median of $d_{k}$.

$$
Q_{i}= \begin{cases}\frac{Q_{n+1}}{2} & \text { if } n \text { is odd } \\ \frac{1}{2}\left(Q_{\frac{n}{2}}+Q_{\frac{n+2}{2}}\right) & \text { if } n \text { is even }\end{cases}
$$

Depending on the sign of $Q_{i}$, the trend can be identified as an increasing or decreasing trend.

\subsection{Pearson Correlation Coefficient}

Pearson correlation coefficient is identified as one of commonly used mathematical coefficients used to measure the statistical relationship or association, in several quantitative variables on each member of a sample[27]. In other words, if there is any linear relationship among two variables, the statistical approach of obtaining that relationship is identified by the Pearson Correlation Coefficient (R). The coefficient is mathematically given by the equation (5).

$$
R=\frac{n \sum x y-\left(\sum x\right)\left(\sum y\right)}{\sqrt{\left[n\left(\sum x^{2}\right)-\left(\sum x\right)^{2}\right]\left[n\left(\sum y^{2}\right)-\left(\sum y\right)^{2}\right]}}
$$

where $n$ is the number of pairs of data and $x=$ $\left\{x_{1}, \ldots \ldots, x_{n}\right\}, y=\left\{y_{1 \ldots \ldots,} y_{n}\right\}$ are two sample data sets. The value of $R$ varies such that $-1 \leq R \leq$ +1 ; where + and - signs of $R$ values indicate positive and negative linear correlations between $x$ and $y$, respectively.

\section{Methodology and Case Study Application}

Samanalawewa reservoir and the hydropower plant are in Sabaragamuwa province and located closer to Balangoda, Aluthnuwara and Belihuloya areas. The area receives a significant rainfall from southwest monsoon (SW monsoon) from May to September. However, this area is known for receiving significant rainfall throughout the year. The hydropower plant is reservoir type with the water contained by a rock fill dam across the upstream of Walawe River. The Samanalawewa catchment has an area about $359 \mathrm{~km}^{2}$ and is one of the important catchments in Sri Lanka. Figure 1 shows the catchment area of Samanalawewa hydropower plant.

Samanalawewa power plant started its power generation in 1992 and it was supposed to produce a maximum of $120 \mathrm{MW}$ of power. Even with a significant leak from the reservoir, the power plant produces an acceptable power generation throughout the year. The leak was initially started at a rate of $7 \mathrm{~m}^{3} / \mathrm{s}$; however, later stabilized to $2.5-2 \mathrm{~m}^{3} / \mathrm{s}$ [10], [28].

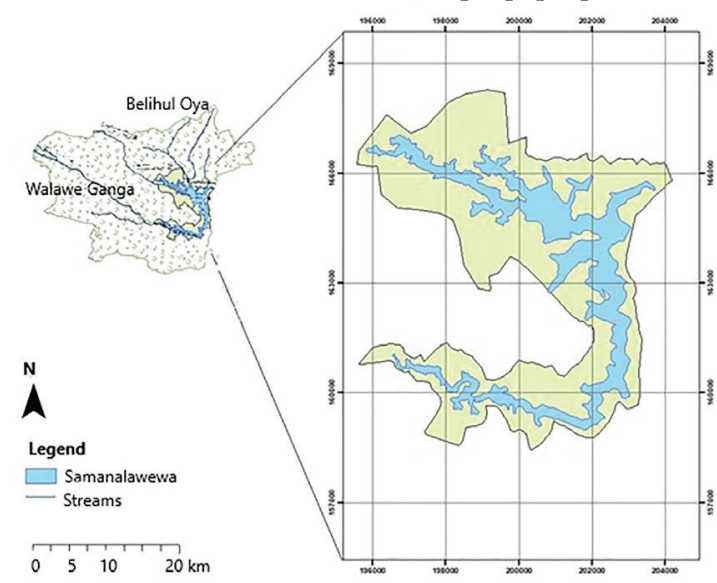

Figure 1 - Samanalawewa Catchment

Monthly rainfall data for six rainfall gauging stations over the catchment from 1992 to 2018 were used in this study. Rainfall data were obtained from Department of Meteorology, Sri Lanka for Balangoda, Alupola, Detanagalla, Belihuloya, Nonpareil (Belehuloya), and Nagrak Estate stations. These stations can be seen in Figure 2.

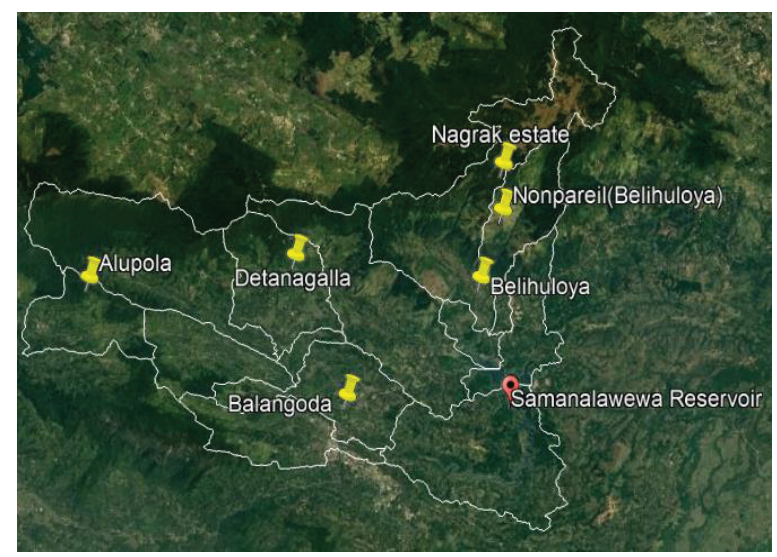

Figure 2 - Rain Gauges in the Catchment

Some of the missing data in rainfall were filled by the normal ratio method. Then, the Pettitt's test, SNHT, Buishand's test and von Neumann's test were carried out on the rainfall data sets to check the homogeneity of data series. Then, the non-parametric test (MannKendall test and Sen's slope estimator test) were carried out for rainfall scales of monthly and annually. Finally, these rainfall data were correlated with the power generation data using Pearson Correlation Coefficient technique. 


\section{Results and Discussion}

Annual rainfall distribution can be seen in Figure 3. The figure clearly shows the zigzag shape of the rainfall over the years. In addition, compared to other years, 1996 had a slightly lower rainfall to the catchment.

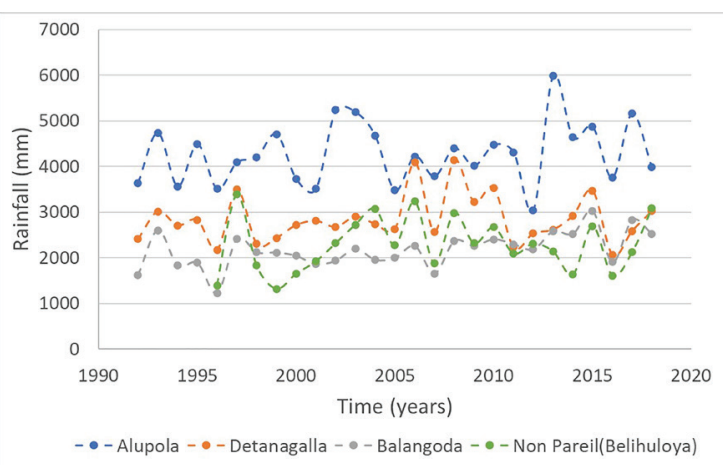

Figure 3 - Annual Rainfall Variation over 26 Years

Tests executed to check the homogeneity of monthly rainfall data show that the monthly data collection is homogenous. Table 1 shows the Mann-Kendall test and Sen's slope analyses results for the annual data. The table demonstrates that there are no significant trends in annual rainfall for five rain gauge stations (Alupola, Detanagalla, Nagarak estate, Belihuloya and Nonpareil (Belihuloya)).
Table 1 - Trend Analysis Results for Annual Rainfall

\begin{tabular}{lcc}
\hline \multicolumn{3}{c}{ Annual Rainfall } \\
\hline Station & $\begin{array}{l}\text { Significant } \\
(S) / \text { Insignificant } \\
(\mathrm{IS})\end{array}$ & $\begin{array}{c}\text { Sen's Slope } \\
(\mathrm{mm} / \text { year })\end{array}$ \\
\hline Alupola & IS & NA \\
\hline Detanagalla & IS & NA \\
\hline Balangoda & S & $\mathbf{2 9 . 8}$ \\
\hline $\begin{array}{l}\text { Nagarak } \\
\text { estate }\end{array}$ & IS & NA \\
\hline Belihuloya & IS & NA \\
\hline Non Pareil & IS & NA \\
\hline
\end{tabular}

Interestingly, positive rainfall trend was identified in Balangoda rain gauge. Therefore, this analysis shows that annual rainfall is increasing in Balangoda area and numerically it is $29.8 \mathrm{~mm}$ per year. This is a significant increase; however, it would be interesting to analyse the seasons or the months of this increase. However, the trend analysis does not specify the possibility of negative rainfall trends in Samanalawewa catchment. The trend analysis suggests that the Samanalawewa catchment is not underneath a serious water shortage situation. This is important to the hydropower generation.

Table 2 - Mann-Kendall Test and Sen's Slope Estimator Test Results for Seasonal Rainfall

\begin{tabular}{|c|c|c|c|}
\hline Rain gauge station & Rainfall season & $\begin{array}{l}\text { Significant (S) } \\
\text { /Insignificant (IS) }\end{array}$ & $\begin{array}{l}\text { Sen's Slope } \\
(\mathrm{mm} / \text { season })\end{array}$ \\
\hline \multirow{4}{*}{$\begin{array}{l}\text { Alupola, } \\
\text { Detangalla, } \\
\text { Nagarak estate } \\
\text { and Non Pareil }\end{array}$} & NE & IS & NA \\
\hline & 1st & IS & NA \\
\hline & SW & IS & NA \\
\hline & 2nd & IS & NA \\
\hline \multirow[t]{4}{*}{ Balangoda } & $\mathrm{NE}$ & IS & NA \\
\hline & 1st & IS & NA \\
\hline & SW & IS & NA \\
\hline & 2nd & $S$ & 13.4 \\
\hline \multirow[t]{4}{*}{ Belihuloya } & $\mathrm{NE}$ & IS & NA \\
\hline & 1st & IS & NA \\
\hline & SW & $S$ & 34.9 \\
\hline & 2nd & IS & NA \\
\hline
\end{tabular}

Notations - NE -Northeast monsoon; 1 st - $1^{\text {st }}$ inter monsoon; SW Southwest monsoon; $2^{\text {nd }}-2^{\text {nd }}$ inter monsoon

As Table 2 indicates two of the rain gauging stations have several significant trends, one in Southwest Monsoon (May - September) and Second-Inter Monsoon (October - November) intermediate season. The results obtained for the analysis of annual rainfall trends show a reasonable concurrence. Though, the Belihuloyara in gauge demonstrates a positive trend in the analysis of seasonal precipitation, it did not appear in the trend analysis of annual 
rainfall. Nevertheless, the increase amount of rainfall for the Belihuloya is around $35 \mathrm{~mm}$ per the Southwest Monsoon. But it should be noted that it is also the rainy season for this area. Therefore, it would be interesting to correlate floods or any rain induced disasters during the past 26 years. Balangoda has an increase of 13.4 $\mathrm{mm}$ of rainfall during the $2^{\text {nd }}$ intermediate season and that would be welcomed by the people who live in that area; however, it is also in the rainy season in Balangoda.

Negative rainfall trends for any of the tested gauging stations were not seen in the analysis. Therefore, it could be justified that the water obtainability within the catchment has not been affected over the 26 years. Therefore, it can be projected that there is no important scarcity for water availability within the Samanalawewa catchment.
The trend analysis was carried to the monthly resolution and the results are given in Table 3. Positive trends can be seen in the monthly resolution too. Positive trends can be seen for Nagarak estate, Belihuloya and Non Pareil (Belihuloya) in May. However, March, November and December months are positive for the Balangoda rain gauge. Thus, monthly rainfall trend analysis shows increased rainfall during the southwest monsoon period.

Interestingly, similar rainfall trends were detected by Khaniya et al. [22] to the Uma Oya catchment, which is near the Samanalawewa catchment. Significantly positive rainfall trends were found in two rain gauging stations (Kirklees estate and Ledgerwatte estate) in the Uma Oya catchment. The positive rainfall trends in annual scale were well supported in the seasonal and monthly scales for the Uma Oya catchment.

Table 3 - Sen's Slope Estimator Test Results for Monthly Rainfall

\begin{tabular}{llccccc}
\hline \multirow{2}{*}{ Month } & \multicolumn{7}{c}{ Sen's slope(mm/month) } \\
\cline { 2 - 7 } & Alupola & Detanagalla & Balangoda & $\begin{array}{l}\text { Nagarak } \\
\text { estate }\end{array}$ & Belihuloya & Non Pareil \\
\hline January & IS & IS & IS & IS & IS & IS \\
\hline February & IS & IS & IS & IS & IS & IS \\
\hline March & IS & IS & 5.8 & IS & IS & IS \\
\hline April & IS & IS & IS & IS & IS & IS, \\
\hline May & IS & IS & IS & 35.4 & 29.7 & IS.4 \\
\hline June & IS & IS & IS & IS & IS & IS \\
\hline July & IS & IS & IS & IS & IS & IS \\
\hline August & IS & IS & IS & IS & IS & IS \\
\hline September & IS & IS & IS & IS & IS & IS \\
\hline October & IS & IS & IS & IS & IS & IS \\
\hline November & IS & IS & 6.1 & IS & IS & IS \\
\hline December & IS & IS & 4.2 & IS & IS & IS \\
\hline
\end{tabular}

Figure 4 demonstrates the generated hydropower from Samanalawewa reservoir hydropower plant since it was in operation (1992).

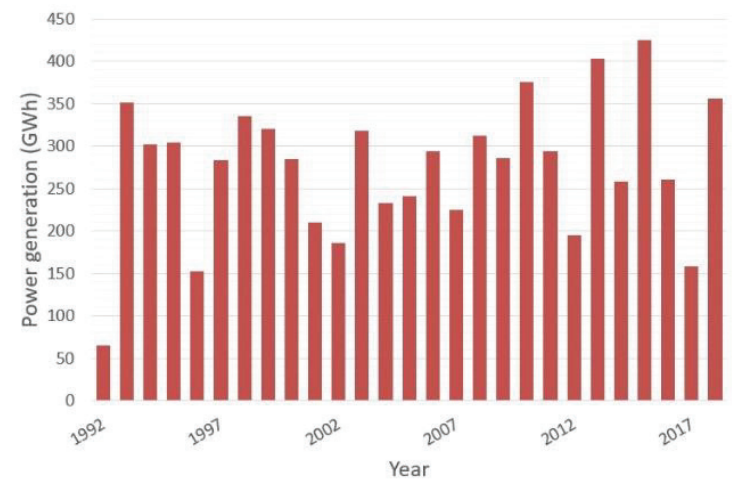

Figure 4 - Annual Power Generation
As it can be seen in many other temporal variations, zigzag variation can be seen in the power generation. Power peaks can be seen in the years 1993, 2010, 2013, 2015 and 2018.

Correlation results are presented in Table 4 and the Pearson's correlation coefficients are found to be 0.3 to 0.65 . This shows that there is generally a relationship among power generation and rainfall time series. Nagarak estate and Balangoda rainfalls have shown somewhat good correlation between the power generations, compared to other rain gauges. However, the non-representation of available rainfall can lead to lower $\mathrm{R}$ values. In addition, the leak from Samanalawewa reservoir may have influenced the results. 
Table 4 - Pearson's Correlation Coefficients of Rainfall and Power Generation

\begin{tabular}{ll}
\hline Rain gauge stations & $\begin{array}{l}\text { Pearson's } \\
\text { correlation } \\
\text { coefficient }\end{array}$ \\
\hline Alupola & 0.42 \\
\hline Detanagalla & 0.41 \\
\hline Balangoda & 0.60 \\
\hline Nagarakestate & 0.65 \\
\hline Belihuloya & 0.50 \\
\hline Non Pareil & 0.30 \\
\hline
\end{tabular}

In addition, the spatial distribution of rain gauges in the catchment may not represent the total catchment characteristic. Therefore, the results can be influenced. Therefore, further analysis is required along the lines of correlation tests. Non-linear analysis, artificial neural networks and gene expression programming might be useful in this case. Therefore, it is highly encouraged to progress the work with non-linear analysis.

\section{Conclusions}

Non-parametric tests suggest that there are several positive rainfall trends in the Samanalawewa catchment during the Southwest monsoon period. Interestingly, the analysis does not show any negative trends in the catchment and that is an interesting conclusion from the analysis. Therefore, there is no instant negative impact on the rainfall due to the on-going climate change. However, even the positive rainfall trend can impose adverse impact especially to the natural disasters. Belihuloua area is prone to frequent landslides and increased rainfall can trigger these landslides during the rainy season. Correlation coefficients suggested that there is no perfect relationship between the catchment's rainfall and the generated power. This could be due to two reasons: selected rain gauges are not perfectly representing the catchment's runoff to the reservoir or there is an influence to the relationship from the significant link. More research on these are proposed to obtain sound conclusions.

\section{References}

1. Deng, Q., Alvarado, R., Toledo, E., and Caraguay, L., “Greenhouse Gas Emissions, Nonrenewable Energy Consumption, and Output in South America: The Role of the Productive Structure", Environmental Science and Pollution Research, 2020, 27(13), pp. 14477-14491.

2. Chapin III, F., Zavaleta, E., Eviner, V., Naylor, R., Vitousek, P., Reynolds, H., Hooper, D. U., Lavorel, S., Sala, O. E., Mack, M. C. and Diaz, S. "Consequences of Changing Biodiversity", Nature, 2000, 405(6783), pp. 234-242.

3. Walther, G. R., Post, E., Convey, P., Menzel, A., Parmesan, C., Trevor, J. C. B., Fromentin, J. M., Hoegh-Guldberg, O. and Bairlein, F. "Ecological Responses to Recent Climate Change", Nature, 2002, 416(6879), pp. 389-395.

4. Nelson, V., Meadows, K., Cannon, T., Morton, J. and Martin, A. "Uncertain Predictions, Invisible Impacts, and the Need to Mainstream Gender in Climate Change Adaptations", Gender $\mathcal{E}$ Development, 2002, 10(2), pp. 51-59.

5. Masika, R.“Gender, Development, and Climate Change", Oxford: Oxfam, United Kingdom, 2002.

6. Schiffer, H., Westhuizen, Z., Radu, C., Ibeanu, N.,Onyekpe, D., Notarianni, E. and Menzel, C. "World Energy Resousers-2016", World Energy Council, England. 2016.

7. Tarroja, B., AghaKouchak, A. and Samuelsen, S. "Quantifying Climate Change Impacts on Hydropower Generation and Implications on Electric Grid Greenhouse Gas Emissions and Operation", Energy III, 2016, pp. 295-305.

8. Ceylon Electricity Board Anual Report. Ceylon Electricity Board, Colombo, Sri Lanka, 2016.

9. Mutunayake, A. P. K. "Stakeholder Perception Management of the Crisis", Engineer, 2015, XLVIII(04), pp. 59-68.

10. Kamal, L. B. "Investigation of Water Leakage Mechanism in the Karstic Dam site, Samanalawewa, Sri Lanka", PhD thesis, Saga University. Japan, 2007.

11. Buishand, T. A. "Some Methods for Testing the Homogeneity of Rainfall Records", Hydrology, 1982,58(1-2), pp. 11-27.

12. Kang, H. and Yusof, F. "Homogeneity Tests on Daily Rainfall Series", International Journal of Computer Applications,Math. Sciences, 2012, 7(1), pp. 9-12. 
13. Wijngaard, J., Tank, K. and K“onnen, G. "Homogeneity of 20th Century European Daily Temperature", International Journal of Climatology, 2003, 23(6), pp. 679-692.

14. Alexandersson, H. "A Homogeneity Test Applied to Precipitation, Journal of Climatology, 19866(6), pp. 661-675.

15. Alexandersson, H. and Moberg, A."Homogenization of Swedish Temperature Data. Part I: Homogeneity Test for Linear Trends", International Journal of Climatology, 1997, 17(1), pp. 25-34.

16. Hofstra, N., Haylock, M., New, M. and Jones, P. "Testing E-OBS European High-Resolution Gridded Data Set of Daily Precipitation and Surface Temperature", Journal of Geophysical Research, 2009, 114(21), pp. 1-16.

17. Sahin, S. and Cigizoglu, H.K. "Homogeneity Analysis of Turkish Meteorological Data Set", Hydrological Processes, 2010, 24(8), pp. 981-992.

18. Haylock, M. R., Hofstra, N., Klein Tank, A. M. G., Klok, E. J., Jones, P. D., and New, M. A."European Daily High-resolution Gridded Data Set of Surface Temperature and Precipitation for 1950-2006", Geophysical Research, 2008, 113(D20), pp. 1-12.

19. Hirsch, R. M. and Slack, J. R. “A Nonparametric Trend Test for Seasonal Data With Serial Dependence", Water Resources Research, 1984, 20(6), pp. 727-732.

20. Karmeshu, N. "Trend Detection in Annual Temperature \& Precipitation Using the Mann Kendall Test - A Case Study to Assess Climate Change on Select States in the Northeastern United States", University of Pennsylvania Scholarly Commons, 2012.

21. Mann, H. B. "Nonparametric Tests Against Trends", Econometrica, 1945, 13 (3), pp. 245-259.

22. Khaniya, B., Jayanayaka, I., Jayasanka, P. and Rathnayake, U. "Rainfall Trend Analysis in Uma Oya Basin, Sri Lanka and Future Water Scarcity Problems in Perspective of Climate Variability", Advances in Meteorology, 2019, pp. 1-10, (ID 3636158).

23. Sen, P. K. "Estimates of the Regression Coefficient Based on Kendall's Tau", Journal of the American Statistical Association, 1968, 63 (324), pp. 1379-1389.

24. Ahmad, I., Tang, D., Wang, T., Wang, M. and Wagan, B. "Precipitation Trends Over Time Using Mann-Kendall and Spearman's Rho Tests in Swat River Basin, Pakistan", Advances in Meteorology, 2015, pp. 1-15.
25. Drápela, K. and Drápelová, I. “Application of Mann-Kendall test and the Sen's slope estimates for detection in deposition data from Bílý Kř́iž (Beskydy Mts., the Czech Republic) 1997-2010", Beskydy, 2011, 4(2), pp. 133-146.

26. Kumar, K. R., Sahai, A. K., Kumar, K. K., Patwardhan, S. K., Mishra, P, K., Revadekar, J. V., Kamala, K. and Pant, G. B. "High-resolution Climate Change Scenarios for India for the 21 ${ }^{\text {st }}$ century", Current Science, 2006, 9(3), pp. 334-345.

27. Puth, M. T., Neuhäuser, M. and Ruxton, G. D. "Effective Use of Pearson's Product-Moment Correlation Coefficient", Animal Behaviour, 2014, 93, pp. 183-189.

28. Laksiri, K., Gunathilake, J. and Iwao, Y. “A Case Study of the Samanalawewa Reservoir on the Walawe River in an Area of Karst in Sri Lanka", Proceedings of the 10th Multidisciplinary Conference (Sinkholes and the Engineering and Environmental Impacts of Karst (GSP 144)),2005 Sept 24-28; San Antonio, TX, USA. 